\title{
Development of a Suite of Tools for Genome Editing in Parageobacillus thermoglucosidasius and Their Use to Identify the Potential of a Native Plasmid in the Generation of Stable Engineered Strains
}

\author{
Matthew S. H. Lau, Lili Sheng, Ying Zhang, and Nigel P. Minton* \\ Cite This: https://doi.org/10.1021/acssynbio.1c00138 \\ Read Online
}

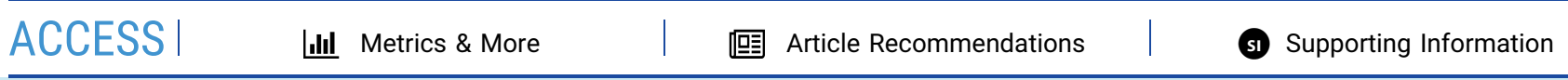

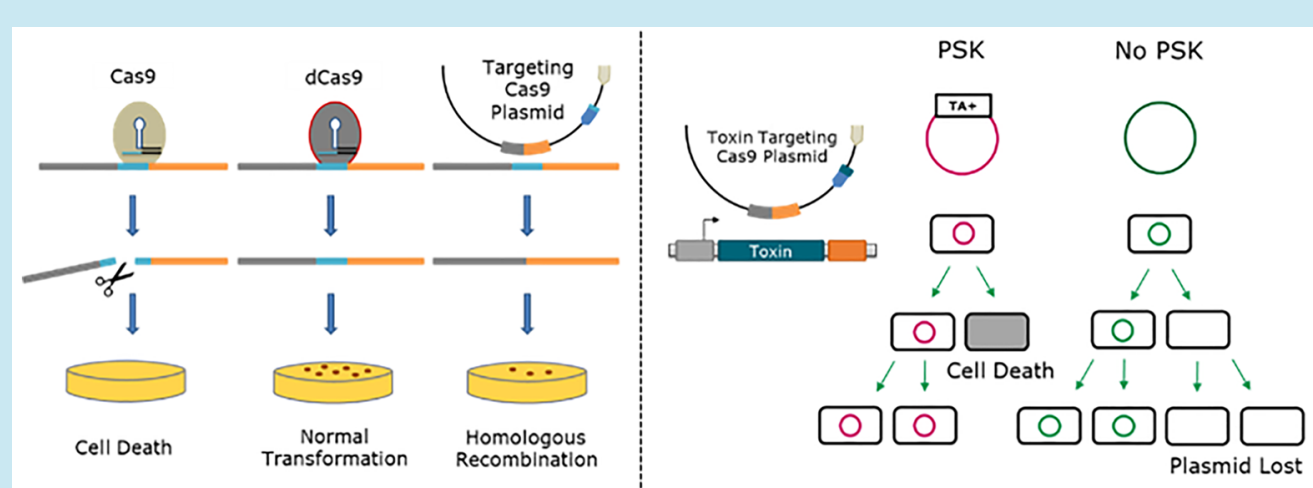

ABSTRACT: The relentless rise in the levels of atmospheric greenhouse gases caused by the exploitation of fossil fuel necessitates the development of more environmentally friendly routes to the manufacture of chemicals and fuels. The exploitation of a fermentative process that uses a thermophilic chassis represents an attractive option. Its use, however, is hindered by a dearth of genetic tools. Here we expand on those available for the engineering of the industrial chassis Parageobacillus thermoglucosidasius through the assembly and testing of a range of promoters, ribosome binding sites, reporter genes, and the implementation of CRISPR/Cas9 genome editing based on two different thermostable Cas9 nucleases. The latter were used to demonstrate that the deletion of the two native plasmids carried by P. thermoglucosidasius, pNCI001 and pNCI002, either singly or in combination, had no discernible effects on the overall phenotypic characteristics of the organism. Through the CRISPR/Cas9-mediated insertion of the gene encoding a novel fluorescent reporter, eCGP123, we showed that pNCI001 exhibited a high degree of segregational stability. As the relatively higher copy number of pNCI001 led to higher levels of eCGP123 expression than when the same gene was integrated into the chromosome, we propose that pNCI001 represents the preferred option for the integration of metabolic operons when stable commercial strains are required.

KEYWORDS: CRISPR/Cas9, genetic tools, thermophile, stable plasmid expression, synthetic biology, curing plasmids

$\mathrm{T}^{\mathrm{k}}$ he chemicals and fuels on which the world relies are predominately derived from fossil reserves. The greenhouse gas emissions that are generated by exploiting these reserves, however, are the principle cause of climate change. Alternative, more sustainable routes to chemicals and fuels are, therefore, required. Microbial-based fermentations, in which renewable feedstocks derived from plant materials are converted into the desired product, represent one of the most promising solutions. The production of such "green" chemicals via this route remains relatively uncommon as the processes involved are generally uncompetitive compared to their conventional, petroleum-based counterpart. One way to improve the competitiveness is to use a more effective microbial chassis. For this, respective thermophilic chassis offer a number of attractions over current model organisms, such as Escherichia coli and Saccharomyces cerevisiae. ${ }^{1-4}$

Thermophilic organisms are often more robust and can withstand fluctuations in temperature, $\mathrm{pH}$, and environmental change, traits that are deemed essential for a commercially viable process. High growth temperatures reduce running costs by limiting contamination by common mesophiles, removing

Received: April 3, 2021 
the need for antibiotics, eliminating the need for cooling between successive fermentation cycles, and facilitating recovery of volatile chemicals through continuous distillation, thereby avoiding the issue of end-product inhibition. ${ }^{3,5-7} \mathrm{~A}$ further significant advantage is that the growth temperatures are optimum for enzymatic lignocellulose degradation, and therefore simultaneous hydrolysis, saccharification, and fermentation can be achieved. ${ }^{8}$ As a consequence, these organisms may be exploited as whole cell biocatalysts in a consolidated bioprocess. ${ }^{9}$ However, currently, the widespread use of thermophiles is hindered by the lack of well-developed genome editing tools that are abundant in their mesophilic counterparts. $^{10-12}$

Parageobacillus thermoglucosidasius (previously called Geobacillus thermoglucosidasius $)^{13}$ is a thermophilic, Gram-positive bacterium and is facultatively anaerobic, with a growth range demonstrated to be between 37 and $68{ }^{\circ} \mathrm{C}^{14}$ It is one of the few thermophiles that can be successfully genetically manipulated and has demonstrated its capability to produce biofuels from lignocellulose, therefore making $P$. thermoglucosidasius a current target for industry. ${ }^{15-18}$ Like many Geobacillus and Parageobacillus species, P. thermoglucosidasius has both a fast growth rate and can ferment a wide variety of sugars.

In an effort to capitalize on the inherent advantages of thermophiles, Cripps et al. (2009) genetically engineered $P$. thermoglucosidasius to produce ethanol as a primary product during fermentation. ${ }^{15}$ The strain created, TM242, produced ethanol at $95 \%$ of theoretical yields when grown on cellobiose as the carbon source. More recently, the same strain was shown to produce ethanol at yields equating to $9.9 \pm 0.4 \mathrm{~g} / \mathrm{L}$ ( $92 \%$ yield) in a fermentation that used palm kernel cake (PKC) as the feedstock, a mannan-rich waste product from palm oil processing. ${ }^{16}$ As the methods used to create TM242 were relatively laborious, we previously described (2017) a less labor-intensive procedure for the creation of knock-ins (KIs) and knockouts (KOs) that exploit the pyrE gene as both a positive and negative selection marker. ${ }^{19}$ While an improvement, the method does not significantly reduce the time needed to generate mutant strains or allow for locationindependent gene KIs.

One solution both to speed up mutant generation and to make it more efficient would be to implement genome editing based on CRISPR (clustered regularly interspaced short palindromic repeats) technology. ${ }^{20}$ This prokaryote-adaptive immune system has been shown to have the ability to identify and selectively cut exogenous DNA. This occurs through the identification of a complementary target called a protospacer and the introduction by a CRISPR-associated protein (Cas) of a lethal double-stranded DNA break downstream of this location at a DNA motif called a protospacer-adjacent motif (PAM). In order to manipulate this system to achieve genome editing, a synthetic guide RNA (sgRNA) is designed, which is complementary to the target site, upstream of the specific PAM. This sgRNA can then guide the Cas protein to the specified targeted sequence, which will cut the DNA. The cas 9 from Streptococcus pyogenes (spCas9) is the most commonly used Cas 9 endonuclease and recognizes a PAM sequence of $5^{\prime}$ NGG-3', making the specific sgRNA sequence $5^{\prime}-\mathrm{N}_{20}-\mathrm{NGG}$ $3^{\prime 20-24}$ Genome editing can then be achieved using DNA repair systems, either nonhomologous end joining in eukaryotes or homology-directed repair in prokaryotes. ${ }^{25,26}$
To date, spCas9 has successfully been exploited for prokaryotic genome editing in several different organisms. ${ }^{25,27-30}$ However, previous studies have demonstrated that spCas 9 is inactive at temperatures above $42{ }^{\circ} \mathrm{C}$, making its use in $P$. thermoglucosidasius challenging. ${ }^{31}$ A thermostable Cas9 from Geobacillus thermodenitrificans has since been identified. $^{32}$ Here we decided to exploit well-characterized CRISPR/Cas9 systems from the moderate thermophile Streptococcus thermophilus ${ }^{33-35}$ and demonstrate the use of both its Cas9 nucleases, stCas91 and stCas93, to generate gene deletions in P. thermoglucosidasius. Exemplification was made possible by the assembly and characterization of a range of regulatory elements to control the expression of the cas genes, including a novel reporter gene encoding a thermophilic florescent protein, eCGP123. The system developed was used to show that deletion of one or both of the two native plasmids present within $P$. thermoglucosidasius, pNCI001 and pNCI002, had no discernible effects on either the growth of the host or metabolites produced. Through the use of the novel reporter and CRISPR/Cas9-mediated insertion of the encoding gene, plasmid pNCI001 was shown to be remarkably segregationally stable. The production of eCGP123 by cells carrying the modified pNCI001 plasmid was higher than when the same gene was inserted into the chromosome. We propose that when stable inheritance of metabolic operons in commercial strains is required pNCI001 represents a preferred option over the chromosome as its higher relative copy number favors elevated production levels.

\section{RESULTS AND DISCUSSION}

Development and Exploitation of a Fluorescence Reporter System for the Characterization of Regulatory Parts. To evaluate the effectiveness of stCas91 and stCas93 in P. thermoglucosidasius NCIMB 11955 as a basis for a genome editing system, effective expression of these nucleases, in combination with their corresponding sgRNA, was required. To identify the most effective promoter systems to accomplish this, a novel reporter system was first established in $P$. thermoglucosidasius based on a thermostable fluorescent protein, eCGP123. ${ }^{36,37}$ Purified eCGP123 protein has previously been shown to fluoresce at $80{ }^{\circ} \mathrm{C}^{36}$ under in vitro conditions and to function in vivo in the thermoacidophilic archaeon Sulfolobus acidocaldarius ${ }^{38}$ but has yet to be evaluated in a bacterium. As superfolder green fluorescent protein (sfGFP) has previously been successfully expressed at high temperature in a number of different thermophilic bacteria, ${ }^{39,40}$ including in $P$. thermoglucosidasius, ${ }^{41}$ the performance of eCGP123 was compared to equivalent constructs made with sfGFP. The two reporter genes were placed under the transcriptional control of the previously characterized $\mathrm{P}_{\text {ldh }}$ promoter and localized to the modular plasmid pMTL61110. ${ }^{17} P$. thermoglucosidasius cells carrying either plasmid were shown to fluorescence to a similar level at 60 ${ }^{\circ} \mathrm{C}$ and to maintain their activity up to and including at $75{ }^{\circ} \mathrm{C}$ (Figure 1). Compared to sfGFP, eCGP123 showed less variation in fluorescence over the temperature range tested and retained higher activity at temperatures greater than $65{ }^{\circ} \mathrm{C}$ (Figure 1).

Having established the suitability of eCGP123 as a reporter system, it was used to compare the effectiveness of a number of different promoters, Shine-Dalgarno (SD), and Rho-independent terminator sequences. Promoters (Table S1) were selected from $P$. thermoglucosidasius genes predicted to be 


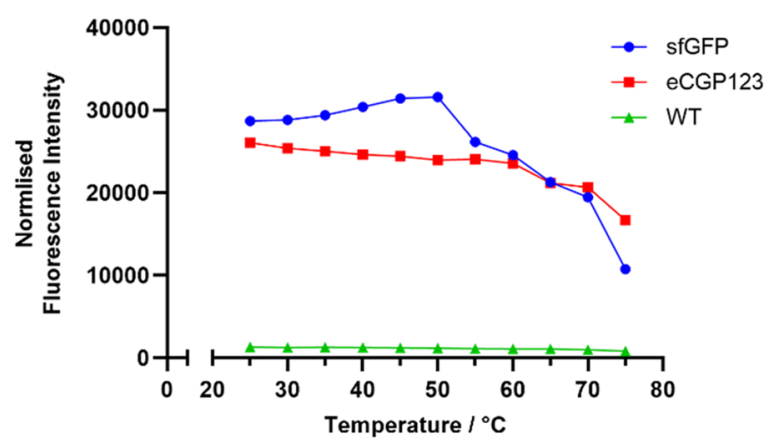

Figure 1. Assay to determine the thermostability of the fluorescent protein markers sfGFP and eCGP123. P. thermoglucosidasius was grown in 2 SPYNG $(50 \mathrm{~mL})$ at $52{ }^{\circ} \mathrm{C}$ under aerobic conditions in a baffled conical flask shaking at $250 \mathrm{rpm}$ for $8 \mathrm{~h}$. Protein lysate was then extracted and quantified using a BugBuster 10X protein extraction reagent and Pierce BCA Protein Assay kit, respectively. The protein lysate of each fluorescent reporter was then incubated, and the level of fluorescence intensity per $\mathrm{mg} / \mathrm{mL}$ of protein was tested at incrementally increasing temperatures.

highly expressed (e.g., from glycolysis or the TCA cycle), whereas the SD (Table S2) and Rho-independent terminator (Table S3) sequences were taken from other organisms, to minimize potential recombination events. Using the fluorescent reporter gene eCGP123, we were able to successfully produce relative strength libraries for promoters, SD sites, and Rho-independent terminators. These libraries have a broad range of expression levels which can be fine-tuned, a necessity for the expression of exogenous genes such as cas 9 (Figure 2).

Construction of CRISPR/Cas9 Genome Editing Vectors for $P$. thermoglucosidasius. To assemble CRISPR/Cas genome editing vectors, a similar architecture to that used in clostridia was adopted. ${ }^{30}$ A crucial difference was that the spCas9 gene was replaced with either the stCas91 or stCas93 genes. Based on the plasmid pMTL61110, these vectors carried the ColEI and pUB110 origins of replication, a thermostable kanamycin resistance gene, the designated cas gene, and a locus encoding the specific sgRNA of the gene being targeted. Our experiments had identified that the two strongest promoters tested were that of the $l d h$ and gapDH genes, $\mathrm{P}_{\text {ldh }}$ and $\mathrm{P}_{\text {gap DH }}$. Accordingly, the stCas genes were placed under the control of $\mathrm{P}_{l d h}$ and the sgRNA under the control of $\mathrm{P}_{\text {gapDH }}$. To prevent transcriptional readthrough, the terminators $\mathrm{T} 1$ and $\mathrm{T} 2$ were positional distal to the sgRNA locus. The two terminators are natively found together in the termination region of the $r r n B$ gene of $E$. coli and has shown to be an efficient terminator. ${ }^{42}$

The PAM sequences of stCas91 and stCas 93 have previously been shown to be 5'-NNAGAAW-3' and 5'-NGGNG-3', respectively. ${ }^{43-48}$ In the initial experiments, sgRNAs incorporating these sequences were designed to target the acetate kinase gene, ack. When vectors, pCas91_Ack and pCas93_Ack, carrying the sgRNA and their respective stCas genes were used in transformation protocols with competent P. thermoglucosidasius cells, no kanamycin-resistant colonies were obtained. This was in contrast to the control plasmid, pCas9, which was lacking in either the sgRNA locus (pMTL575555 and pMTL675555) or both the cas gene and the sgRNA (pMTL61110), in which both produced a typical transformation efficiency of around $1 \times 10^{4}$ colonies. These observations are consistent with the fact that the stCas enzymes being produced were being successfully targeted to
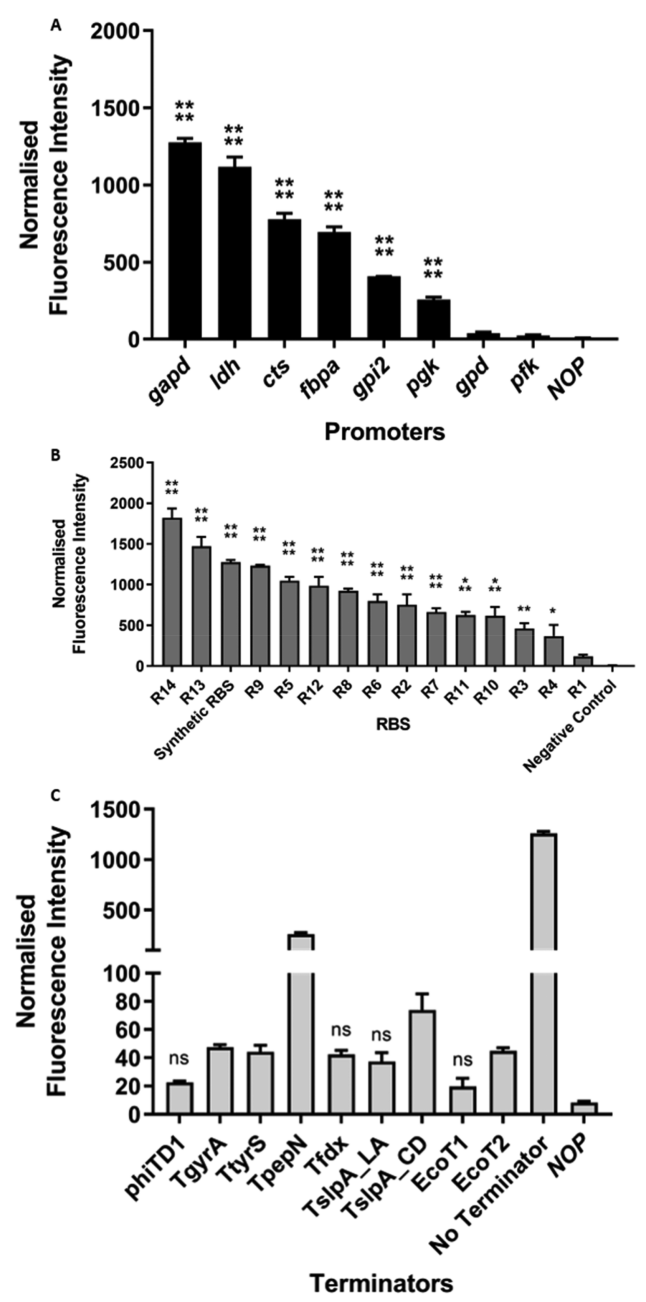

Figure 2. Relative strengths of promoters, ribosomal binding sites (RBSs), and rho-independent terminators tested in P. thermoglucosidasius as determined by the relative fluorescence units (RFUs) of eCGP123 expression normalized to protein concentration $(\mathrm{mg} / \mathrm{mL})$. P. thermoglucosidasius was grown in 2 SPYNG $(50 \mathrm{~mL})$ at $52{ }^{\circ} \mathrm{C}$ under aerobic conditions in a baffled conical flask shaking at $250 \mathrm{rpm}$ for 8 h. (A) Promoters from left to right are as follows: those derived from the genes encoding glyceraldehyde 3-phosphate dehydrogenase $($ gapd $)$, lactate dehydrogenase $(l d h)$, citrate synthase $(c t s)$, fructosebisphosphate aldolase $(f b p a)$, glucose-6-phosphate isomerase 2 (gpi2), phosphoglycerate kinase (pgk), glycero-3-phosphate dehydrogenase ( $g p d)$, 6-phosphofrucokinase ( $p f k$ ), and no promoter (NOP). All promoters originate from $P$. thermoglucosidasius with the exception of ldh which originates from Geobacillus thermodenitrificans. (B) The RBS library contained Shine-Dalgarno sequences from Clostridium botulinum as well as a negative control consisting of no concensus RBS sequence. The promoter, $\mathrm{P}_{\text {gapd }}$, remained constant throughout each of the RBS constructs. Statistical analysis was carried out using Graphpad Prism 7.03. A one-way analysis of variance (ANOVA) with a Dunnett's method post hoc analysis was used to determine whether the data presented from a sample were statistically different from the control. $P$ values $\leq 0.05$ were considered statistically significant and are represented by asterisks. The following asterisk format is used throughout: $* p \leq 0.05$, ** $p \leq 0.01, * * * p \leq 0.001$, **** $p \leq 0.0001$. (C) Rho-independent terminators were expressed downstream of the promoter $\mathrm{P}_{\text {gapd }}$ used to express eCGP123. All the terminators show a statistically significant decrease compared to the sample containing no terminator. The samples showing no statistical difference compared to no promoter (NOP) are denoted by ns. The error bars on the graph denote the standard error of the mean $(n=3)$. 
the ack gene, and the resultant double-strand DNA breaks generated could not be repaired by $P$. thermoglucosidasius, rendering the transformed cells nonviable. To confirm that the failure to obtain transformants was due to lethal cleavage of the host chromosome, the two cas9 genes (stcas91 and stcas93) were deliberately inactivated through the introduction of a frame-shift mutation, at their unique PacI and Eco81I sites, respectively, producing $\mathrm{p} \Delta \mathrm{Cas} 9$ (Materials and Methods). The plasmids carrying these frameshift mutations transformed $P$. thermoglucosidasius at equivalent frequencies to those observed with plasmids not carrying a cas9 gene, a result also observed by Sapranauskas et al. (2011) in E. coli. ${ }^{49}$ Taken together, these data indicated that both $S$. thermophilus enzymes are functional at the elevated temperature used for growth of $P$. thermoglucosidasius, at $52{ }^{\circ} \mathrm{C}$.

Cas9-Induced Knockout of Genes through Homologous Recombination. Having established that both stCas9 enzymes were active at $52{ }^{\circ} \mathrm{C}$ in $P$. thermoglucosidasius, plasmids were assembled equivalent to pCas91_Ack and pCas93_Ack but which additionally carried an ca. $1000 \mathrm{bp}$ editing template comprising $500 \mathrm{bp}$ homology arms (HAs) that flanked the ack gene. Replacement of the WT ack gene with this mutant allele by homologous recombination (HR) would result in an in-frame deletion mutant. The two plasmids created, pCas91_Ack_hr and pCas93_Ack_hr, successfully transformed $P$. thermoglucosidasius. The number of kanamycinresistant colonies obtained from transformations, however, was significantly lower, $<20$ colonies, than control plasmids in which the stCas genes were inactivated. PCR screening of colonies using oligonucleotide primers flanking the ack gene, following restreak of primary transformants onto selective agar media, demonstrated that a DNA band of a size consistent with deletion of ack, $1.2 \mathrm{~kb}$, had occurred in 5 out of 12 colonies for stCas91 and 10 out of 10 colonies for stCas93 (Figure 3a). However, a band equivalent to the WT allele, $2.4 \mathrm{~kb}$, was also present. Cells from such colonies were, therefore, subjected to six sequential passages of $12 \mathrm{~h}$ at $52{ }^{\circ} \mathrm{C}$ in fresh 2 SPYNG km media before being screened again, all of which were now composed of pure mutants. Elimination of ack was selected due to evidence of successful deletion in many different species, including thermophiles, such as E. coli, C. acetobutylicum, and Thermoanaerobacterium saccharolyticum. ${ }^{50-52}$ Due to the function of ack in the mixed acid fermentation pathway, it is often deleted to improve expression of valuable products.

Having demonstrated that both stCas 9 enzymes could be used for genome editing, two further genes were targeted, lactate dehydrogenase (Ldh) and alcohol dehydrogenase (AdhE). In this case, only plasmids based on stCas93 were constructed, as its PAM is more ubiquitous than that of stCas91 and, therefore, provides greater scope for mutant generation. In the case of ack, for instance, 35 targets were present for stCas 93 compared to 4 for stCas91. Furthermore, stCas 93 demonstrated an increased efficiency to produce the ack mutant than stCas91, a result that has also previously been observed by Muller et al. (2016) in human cells. ${ }^{46}$ Accordingly, vectors equivalent to those used to knockout ack were constructed for both $l d h$ and $a d h E$, and a similar protocol was used to generate in-frame deletion mutants (Figure $3 \mathrm{~b}$ ), as evidenced by the presence of a foreshortened DNA fragment. To rule out the possibility of a translocation event, a PCR containing internal primers was performed to ensure deletion of the gene in question (Figure 3c). Like $a c k, l d h$ and $a d h E$ are often key targets in the production of industrially significant
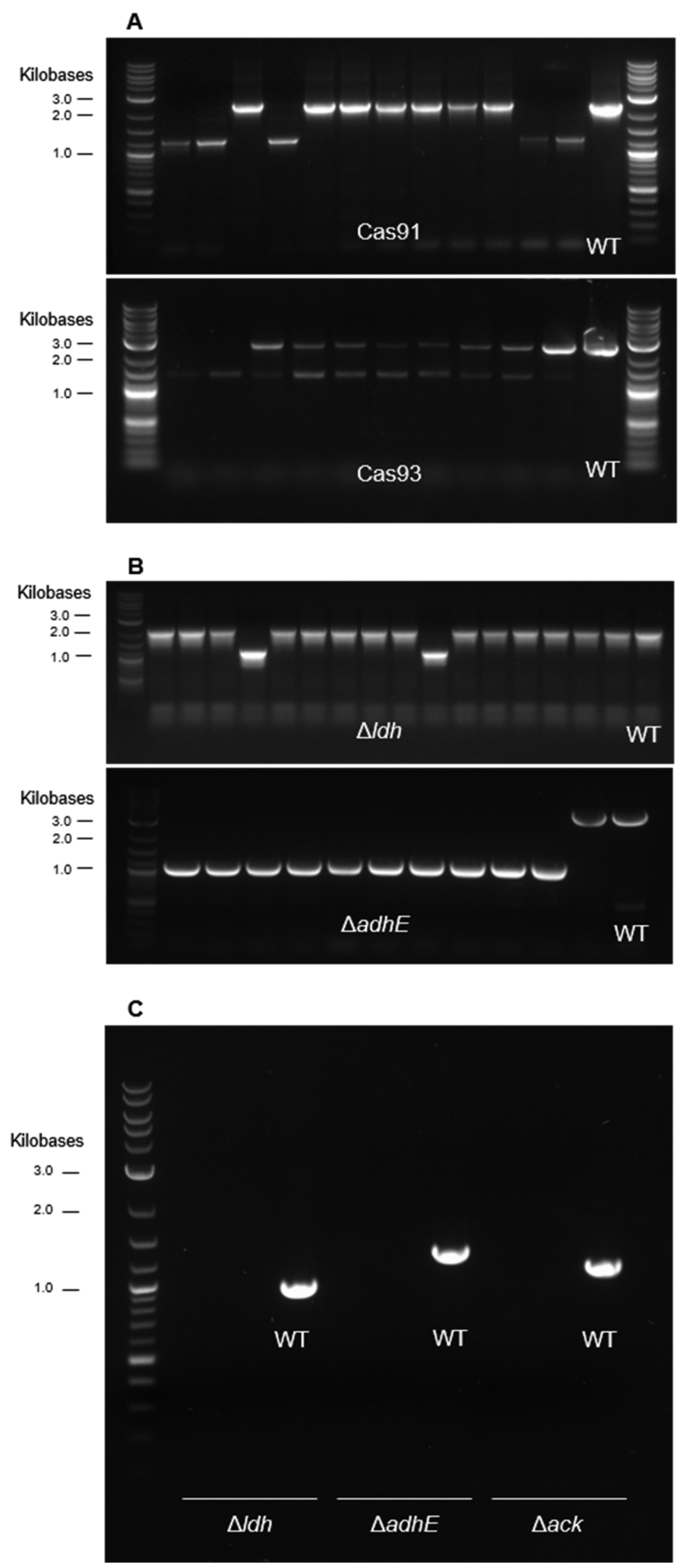

Figure 3. (A) Gel electrophoresis image of a colony PCR, utilizing Ack_F and Ack_R primers, to assess whether the acetate kinase (ack) gene had been successfully knocked out of the $P$. thermoglucosidasius genome using stCas9-1 and stCas9-3. A PCR of WT ack was performed as a control $(\sim 2.4 \mathrm{kB})$. Colonies that have the $\Delta a c k$ would yield a band at $\sim 1.2 \mathrm{kB}$. A 2-log DNA ladder was used to determine the size of each band. (B) A gel electrophoresis image of a colony PCR performed to assess whether the genes encoding lactate dehydrogenase $(l d h)$ and aldehyde-alcohol dehydrogenase (adhE) had been knocked out of the $P$. thermoglucosidasius genome. The primers used were (ldh) CP_LDH_F and CP_LDH_R and ( $a d h E)$ CP_ADH_F and CP_ADH_R. A PCR of each WT gene was performed as a control $(\sim 2.1 \overline{\mathrm{kB}}$ and $\sim 3.7 \mathrm{kB}$, respectively). Colonies that had the successful gene deletion would yield a band at $\sim 1.1 \mathrm{kB}$. A 2-log DNA ladder was used to determine the size of each band. (C) A gel electrophoresis image of a colony PCR was performed to confirm loss of the genes, lactate dehydrogenase (ldh), aldehyde-alcohol 
Figure 3. continued

dehydrogenase $(a d h E)$, and acetate dehydrogenase (ack), from the $P$. thermoglucosidasius genome. The internal gene primers were (ldh) LDH_Inter_F LDH_Inter_R, (adhE) $\mathrm{ADH}$ _Inter_F ADH_Inter_R, and (ack) ACK_Inter_F ACK Inter R. Amplification of the internal primers yields bands at $\sim 0.9 \mathrm{~kb}, \sim 1 . \overline{\mathrm{kb}}$, and $\sim 1.2 \mathrm{~kb}$, respectively. A 2-log DNA ladder was used to determine the size of each band.

strains, to manipulate the metabolism of an organism, due to their role in mixed-acid fermentation, hence validating their inclusion into the study.

Curing of $P$. thermoglucosidasius Native Plasmids Using CRISPR/Cas9. Like many species of Geobacillus and Parageobacillus, $P$. thermoglucosidasius NCIMB 11955 contains two large plasmids, pNCI001 $(\sim 85 \mathrm{~kb})$ and pNCI002 $(\sim 49$ $\mathrm{kb})$. As the maintenance of plasmid DNA by a cell has a metabolic cost, ${ }^{53,54}$ it would be expected that the burden imposed is counteracted by a plasmid-endowed attribute of benefit to the cell. The role of pNCI001 and pNCI002, however, remains cryptic as neither plasmid sequence has provided clues as to their function. ${ }^{55}$ One way to ascribe function would be to isolate cured derivatives of $P$. thermoglucosidasius that no longer carry the plasmids and compare their phenotypes to the WT. ${ }^{56-58}$ Normally achieved using negatively selectable markers, ${ }^{56,57,59}$ this could now be achieved by using the developed CRISPR system to target the genes encoding the replication proteins of pNCI001 and pNCI002, RepB (BCV53 19210, BCV53 19380), and RepA (BCV53_19650), respectively. ${ }^{55}$ Accordingly, stCas93-based KO plasmids were designed, carrying appropriate sgRNAs and editing templates comprised of a mutant rep gene allele. Following the transformation of $P$. thermoglucosidasius with the CRISPR plasmid targeting repA, 16 kanamycin-resistant colonies were screened, and all 16 were shown to be lacking plasmid pNCI002, as evidenced from the absence of an appropriately sized amplified DNA fragment in a colony PCR using oligonucleotide primers specific to the plasmid (Figure 4a). In contrast, no transformants were obtained using the CRISPR plasmid that targeted the repB gene of plasmid pNCI001.

On the face of it, these experiments demonstrate that pNCIO02 is not essential and that pNCI001 may play an essential role under the conditions tested. A closer inspection of the pNCI001 sequence, however, indicated the presence of a putative toxin/antitoxin system. These typically ensure plasmid survival through post segregationally killing (PSK) as a consequence of the significant differences in the half-lives of its two components. ${ }^{60}$ In essence, the lethal effects of the toxin are nullified by the antidotal antitoxin. However, if the cell simultaneously loses the ability to produce both components as a consequence of losing the plasmid/genes, then the significantly reduced half-life of the antitoxin compared to that of the toxin means that the cell is rapidly killed. ${ }^{60,61}$ Hence, no transformants were obtained when $P$. thermoglucosidasius was transformed with a CRISPR plasmid that prevented the replication of plasmid pNCI001 and by inference replenishment of cellular levels of the antitoxin. Plasmid maintenance in this way is a commonly reported phenomenon to maintain DNA, be it through maintaining plasmids or the stabilization of specific areas of chromosomal DNA. ${ }^{60-65}$

If the toxin/antitoxin system prevents the loss of pNCI001, then the prior inactivation of the toxin gene, while maintaining
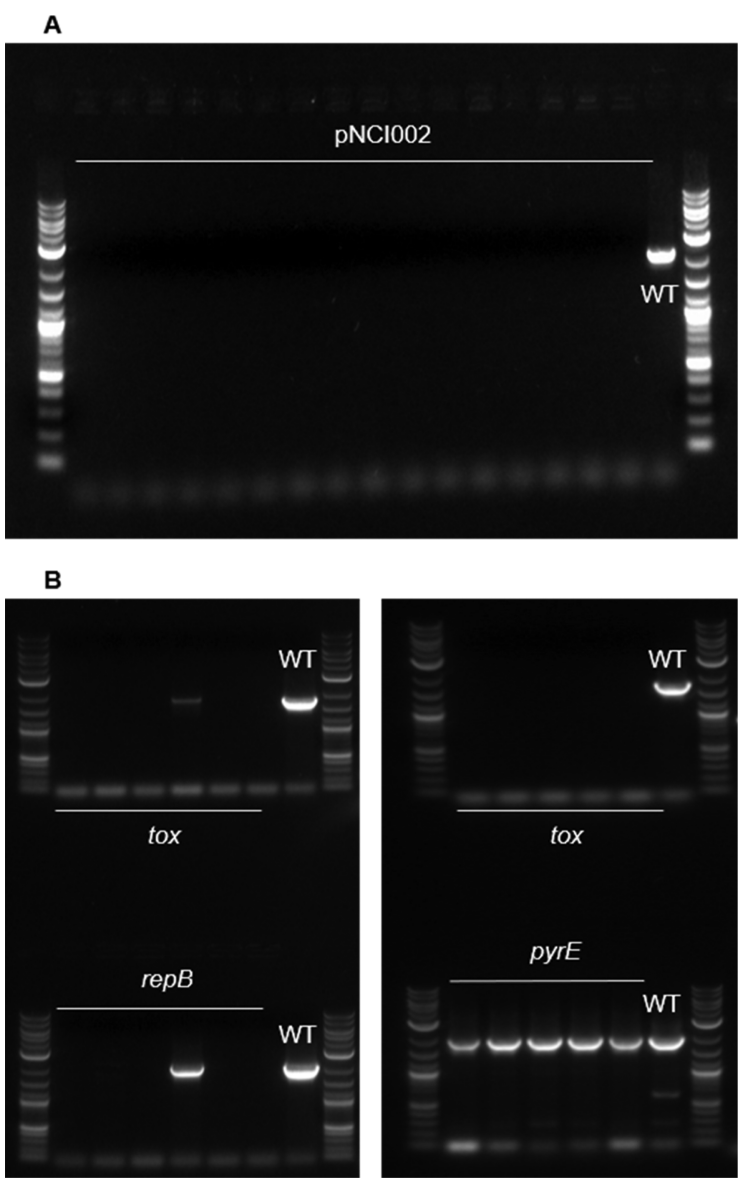

Figure 4. Gel electrophoresis image of colony PCR to assess the poresence of the plasmids in P. thermoglucosidasius. (A) SMPR_CP_F and SMPR_CP_R primers were used to assess whether the $\mathrm{pNCIO0} 2$ replication gene (repA) had been knocked out. A PCR of the WT repA was performed as a control $(\sim 2.2 \mathrm{kB})$. Colonies containing $\triangle$ repA would yield a band at $\sim 1.2 \mathrm{kB}$. However, no PCR product was observed when ran on a $1 \%$ agarose gel, indicating the complete loss of the small plasmid (pNCI002). (B) A colony PCR to show the loss of pNCI001 from P. thermoglucosidasius. Two separate PCR reactions were carried out on the same colony. PCR of the tox gene utilized the primers Tox_CP_F and Tox_CP_R, and the repB replication gene used the primers $\mathrm{BMPR} C \mathrm{CP}_{\mathrm{F}}$ and BMPR CP R. A PCR of the WT tox gene and the rep $\bar{B}$ was performed as a control $(\sim 1.8 \mathrm{~kb}$ and $\sim 2.3 \mathrm{~kb}$, respectively). Colonies containing $\Delta$ tox would yield a band at $\sim 1.3 \mathrm{~kb}$. However, no PCR product was observed when ran on a $1 \%$ agarose gel, indicating the complete loss of the pNCI001. The unsuccessful PCR of the repB further confirmed this finding. A colony PCR of the $\triangle r e p B$ mutants was performed to confirm the strain as $P$. thermoglucosidasius. PCR of pyrE was performed, utilizing the primers PyrE_F and PyrE_R, alongside a PCR of tox, as performed previously. PCR of WT pyrE was implemented as a control $(\sim 1.7 \mathrm{~kb})$. A 2-log DNA ladder was used to determine the size of each band.

a functional antitoxin gene, would allow the plasmid to be subsequently cured. Accordingly, a CRISPR KO plasmid was designed that would introduce the desired mutation into the toxin gene. It was anticipated that the mutant plasmid generated could be subsequently cured from the cell by targeting repB with the previously constructed CRISPR KO vector. Surprisingly, when CRISPR/Cas vectors that targeted the toxin gene were introduced into $P$. thermoglucosidasius, the plasmid pNCI001 was lost immediately. Post-transformation, 5 out of 6 colonies tested showed clean mutants, without any 
further action to target $\operatorname{repB}$, or any additional passages, being necessary (Figure $4 \mathrm{~b}$ ). Hence, it would appear that pNCI001 is inherently unstable and that its maintenance is entirely dependent on the toxin/antitoxin system. ${ }^{66}$ It is also apparent that the plasmid is not essential. Having cured $P$. thermoglucosidasius of pNCI001, the derivative strain was transformed with the CRISPR plasmid targeting the repA gene of pNCI002 to generate a derivative plasmid-free strain lacking both large plasmids.

Phenotypic characterization of $P$. thermoglucosidasius strains lacking one or other of the plasmids, or both, failed to find any differences to the WT. Thus, there were no discernible differences in the growth rates of the four strains (Figure 5).
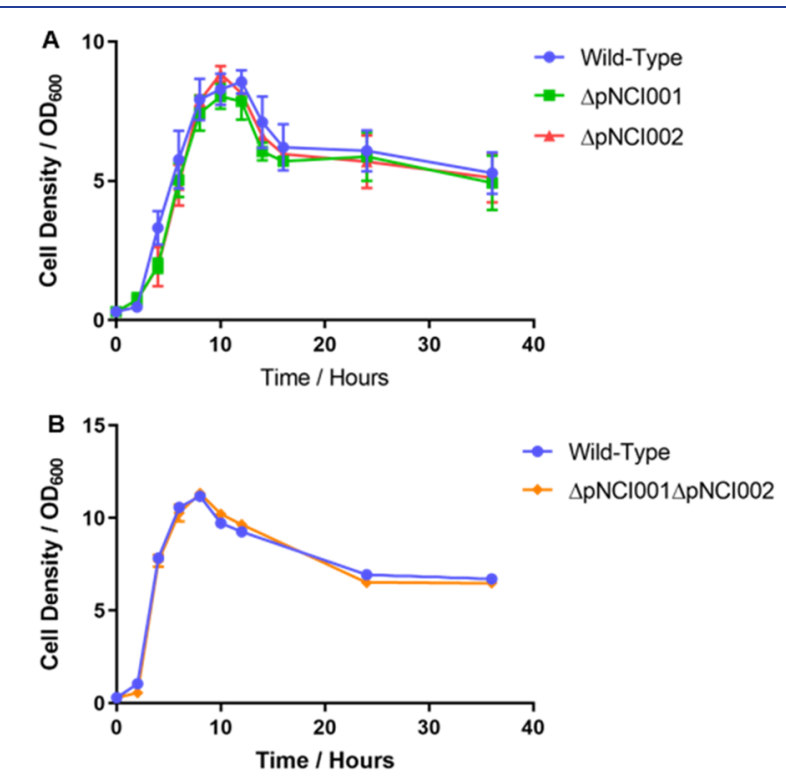

Figure 5. Growth curves of the plasmid-deficient strains of $P$. thermoglucosidasius in a defined medium, monitoring the effect on growth over a $36 \mathrm{~h}$ time period resulting from the (A) single and (B) double plasmid loss, compared to wild-type. The error bars on the graph denote the standard error of the mean $(n=3)$, Growth of $P$. thermoglucosidasius was performed under aerobic conditions at $60{ }^{\circ} \mathrm{C}$ in a baffled conical flask in modified ASYE $(50 \mathrm{~mL})$ and supplemented with $1 \%$ glycerol.

Accordingly, neither plasmid, alone nor in combination, conferred either a growth advantage or a metabolic burden on the cell. Furthermore, high-performance liquid chromatography-ultraviolet (HPLC-UV) analysis of the culture supernatant indicated no apparent change in metabolite production or in the extent of glycerol utilization between the mutants and the WT (Figure S1).

Exploiting pNCI001 as a Stable Locus for Heterologous Genes. Indirect evidence suggests that the two large plasmids exhibit a high degree of segregational stability in $P$. thermoglucosidasius NCIMB 11955. Thus, derivatives of NCIMB 11955 that have lost either plasmid have not been reported, despite the fact that they apparently confer no advantage on the host. Such a degree of segregational stability is not a feature of the small autonomous plasmids routinely used to clone the heterologous genes into NCIMB 11955, where plasmid retention is reliant on the supplementation of media with selective antibiotics, principally kanamycin. The segregational stability of introduced genes without the need to supplement media is a fundamental requirement of any industrial process. Traditionally, such stability is achieved through the introduction of genes into the chromosome, where gene loss is unlikely to occur but productivity is significantly reduced compared to the use of small cloning vectors due to the decreased gene dosage. In this respect, plasmids pNCI001 and pNCI002 may represent superior alternatives to the chromosome as the coverage data obtained previously ${ }^{55}$ suggest their copy number is higher than that of the chromosome. $^{67}$

To test our hypothesis, we designed a series of stCas93based CRISPR vectors, carrying: (i) a sgRNA under the transcriptional control of the $\mathrm{P}_{\text {gapdh }}$ promoter targeting the region downstream of pyrE or pseudogenes within plasmids pNCI001 and pNCI002, BCV53_19490, and BCV53_19815, repectively; (ii) the eCGP123 gene under the control of the $\mathrm{P}_{\text {ldh }}$ promoter and the synthetic RBS sequence; and (iii) the requisite HAs flanking the eCGP123 to support its insertion into the targeted locus (see Materials and Methods for details). Following transformation of the various vectors into $P$. thermoglucosidasius as previously described, kanamycin-resistant cells were passaged twice to produce the desired mutants and then screened. The editing plasmid was then cured, and the successful KI was detected by PCR and also identified by detecting the fluorescence produced by the reporter protein. The generation of mutant cell lines in which the eCGP123 was inserted into the chromosome downstream of pyrE was readily achieved (Figure $6 \mathrm{a}$ and $\mathrm{b}$ ). Similarly, it proved possible to readily obtain derivatives of pNCI001 carrying the eCGP123 gene inserted within the pseudo gene BCV53_19490. However, despite numerous attempts, it did not prove possible to insert the gene encoding eCGP123 into the pseudogene BCV53_19815 of plasmid pNCI002. This unsuccessful insertion into pNCI002 validates the already indicated nonessential nature of $\mathrm{pNCI002}$. It is proposed that, instead of undergoing HR to replace the protospacer targeted by the Cas9, pNCI002 is instead cured by the double-stranded break caused by the Cas9. This signifies that there is no selection pressure conserving pNCI002. Unlike pNCI001, pNCI002 contains no observed toxin-antitoxin module to ensure the survival of the plasmid.

Having generated strains in which the eCGP123 gene had been localized to either the chromosome, plasmid pNCI001, and through the previous standard cloning procedures, to the multicopy cloning vector pMTL61110, it was possible to evaluate the relative effects of gene dosage on heterologous gene expression. The levels of fluorescence of the three strains are illustrated in Figure 7a. As predicted, the highest levels of fluorescence were seen in cells where the eCGP123 was localized to the multicopy pMTL61110, and the lowest levels were seen when the gene had been inserted into the chromosome. While cells in which the eCGP123 gene had been inserted into pNCI001 exhibited much lower fluorescence than those cells carrying pMTL61110::eCGP123, they exhibited significantly higher levels of expression than when the gene was in the chromosome (Figure 7a). Furthermore, the suggestion that pNCI001 is stability maintained was confirmed through screening of 14 colonies which were confirmed to maintain the plasmid pNCI001 and the inserted eCGP123 gene (Figure 7b).

\section{MATERIALS AND METHODS}

Biological Material and Growth Conditions. The bacterial strains used in this study are listed in Table S4. 

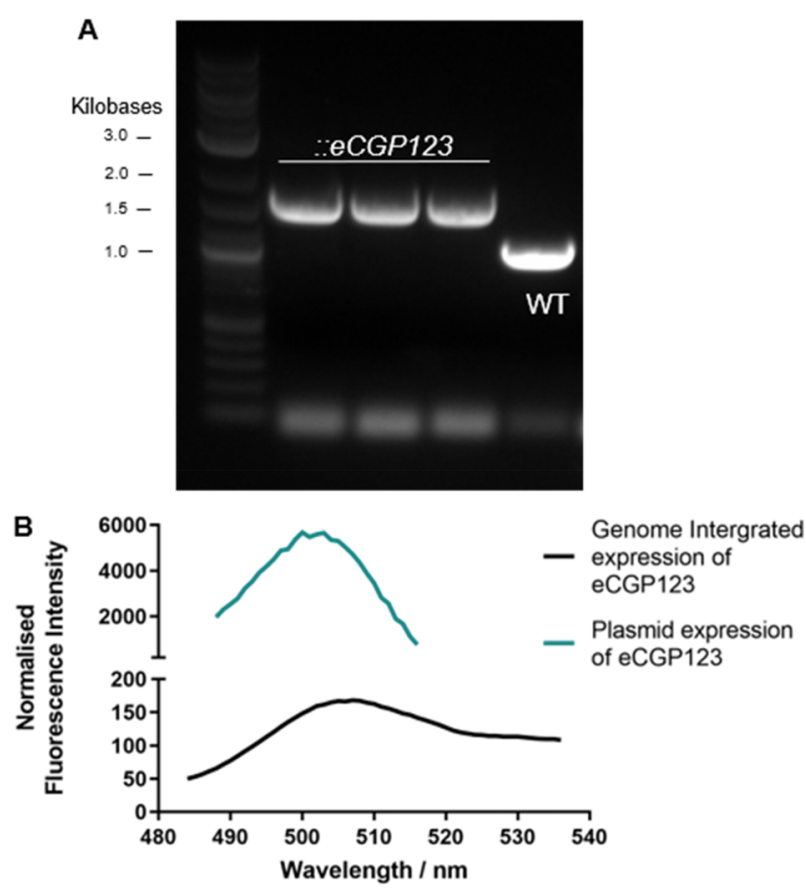

Figure 6. (A) Gel electrophoresis image of a colony PCR, utilizing CP_Genome_eC_F and CP_Genome_eC_R primers, to assess whether the eCGP123 reporter gene had been knocked-in to the genome of $P$. thermoglucosidasius, downstream of pyrE. A PCR of WT $P$. thermoglucosidasius was performed as a control $(\sim 1.1 \mathrm{~kb})$. Colonies that have the::eCGP123 would yield a band at $\sim 1.6 \mathrm{~kb}$. A 2-log DNA ladder was used to determine the size of each band. (B) A spectral scan $(484-536 \mathrm{~nm})$ of the protein lysate extracted from the strain::eCGP123, demonstrating an increase in normalized relative fluorescent units (RFUs), indicating the presence of the eCGP123 gene. The normalized fluorescence intensity of plasmid-based expression of eCGP123 is also displayed to demonstrate the difference in expression level.

E. coli Top10 strain (Invitrogen) was used as a cloning host and grown in LB media $(5 \mathrm{~mL})$ or on $\mathrm{LB}$ agar plates at $37^{\circ} \mathrm{C}$ and supplemented with kanamycin $(50 \mu \mathrm{g} / \mathrm{mL})$. LB broth contains tryptone $(10 \mathrm{~g})$, yeast extract $(5 \mathrm{~g})$, and $\mathrm{NaCl}(5 \mathrm{~g})$ per liter of deionized water. The $\mathrm{pH}$ of the media was adjusted to 7.5 using $\mathrm{HCl}$ or $\mathrm{NaOH}$ prior to autoclaving. $\mathrm{LB}$ agar was prepared by the addition of No. 1 bacteriological agar (10 g) per liter of deionized water before being autoclaved.

For general growth, P. thermoglucosidasius NCIMB 11955 (TMO Renewables) was grown in $2 \mathrm{SPYNG}(5 \mathrm{~mL})$ at $52{ }^{\circ} \mathrm{C}$ shaking $(250 \mathrm{rpm}) \mathrm{O} / \mathrm{N}$ or on TSA agar plates at $52{ }^{\circ} \mathrm{C}, \mathrm{O} / \mathrm{N}$. Where appropriate, kanamycin $(12.5 \mu \mathrm{g} / \mathrm{mL})$ was used for selection of plasmids. For development of tools, $P$. thermoglucosidasius was grown in 2SPYNG $(50 \mathrm{~mL})$ at $52{ }^{\circ} \mathrm{C}$ in a baffled conical flask for $8 \mathrm{~h}$. For the generation of mutants using CRISPR/Cas9 technology, $P$. thermoglucosidasius was grown in 2 SPYNG $(10 \mathrm{~mL})$ at $52{ }^{\circ} \mathrm{C}$ in a falcon tube for $12 \mathrm{~h}$ before being passaged into fresh media, until a clean mutant was produced. Plasmid loss was carried out using 2 SPYNG (10 $\mathrm{mL}$ ) without antibiotic selection at $60^{\circ} \mathrm{C}$. 2 SPYNG contained soy peptone $(16 \mathrm{~g})$, yeast extract $(10 \mathrm{~g})$, and $\mathrm{NaCl}(5 \mathrm{~g})$ per liter of deionized water. The $\mathrm{pH}$ was adjusted to 7.0 using $5 \mathrm{M}$ $\mathrm{KOH}$ prior to autoclaving. TSA agar was prepared using TSA $(40 \mathrm{~g})$ (Sigma-Aldrich) per liter of deionized water and autoclaved.
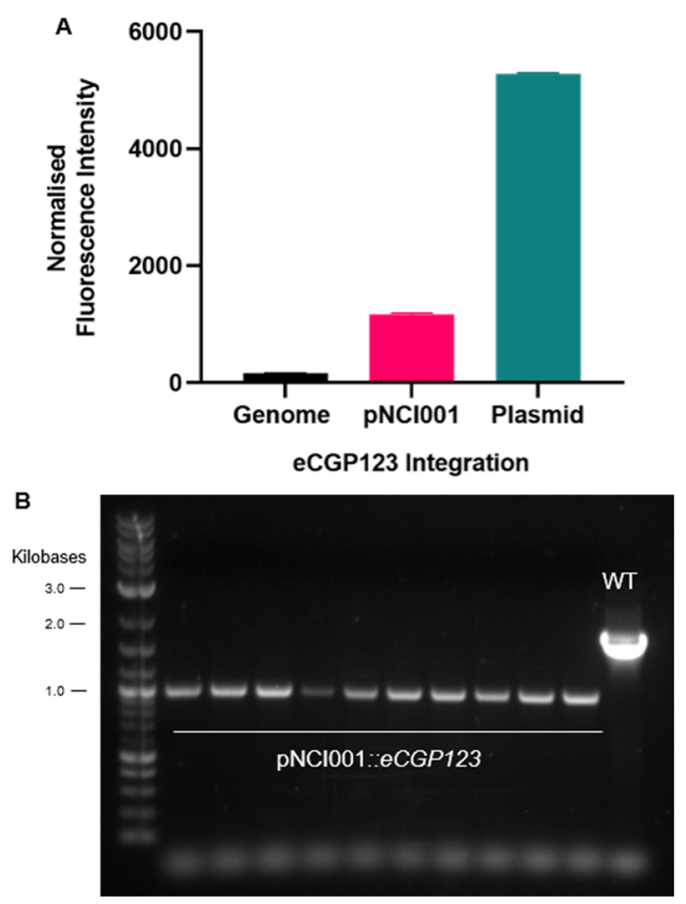

Figure 7. (A) Graph demonstrating the normalized fluorescence intensity of eCGP123 which was expressed on the genome, the plasmid pNCI001, and the plasmid pMTL6110. (B) A gel electrophoresis image of a colony PCR, utilizing $\mathrm{CP}$ BMP eC $\mathrm{F}$ (outside of $\mathrm{HC}$ ) and CP_BMP_eC_R (inside of $\mathrm{HC}$ ) primers, to assess whether the eCGP123 reporter gene had been knocked-in to the pseudo gene, BCV53_19490, in the plasmid pNCI001 of $P$. thermoglucosidasius $(\sim 1 \mathrm{~kb})$. A PCR of WT P. thermoglucosidasius was performed as a control reaction using the primers CP_BMP_eC_F and CP_BMP_eC_R2 $(\sim 1.6 \mathrm{~kb})$. A 2-log DNA ladder was used to determine the size of each band.

Growth of bacterial cultures in liquid medium was monitored by measuring optical density at $600 \mathrm{~nm}\left(\mathrm{OD}_{600}\right)$ using a Jenway 6300 (Cole-Parmer). Samples measured were diluted to $1 \times 10^{-1}$.

For transformation of $P$. thermoglucosidasius, 2SPY was used. This was produced in the same way as 2 SPYNG but included glycerol $(10 \mathrm{~g})$. The $\mathrm{pH}$ was adjusted to 7.0 using $5 \mathrm{M} \mathrm{KOH}$ prior to autoclaving.

For characterization of the plasmid-deficient strains, $P$. thermoglucosidasius was grown in modified ASYE $(50 \mathrm{~mL})$ at $60{ }^{\circ} \mathrm{C}$ in a baffled conical flask. Modified ASYE was prepared according to Lin et al. (2014), ${ }^{8}$ consisted of $0.5 \%$ yeast extract, $2 \mathrm{mM} \mathrm{MgSO} 4(0.24 \mathrm{~g})$, thiamine $(0.01 \mathrm{~g})$, citric acid $(0.384$ g), $\mathrm{FeSO} 4 \cdot 7 \mathrm{H}_{2} \mathrm{O}(27.8 \mathrm{mg}), \mathrm{NiCl}_{3} \cdot 6 \mathrm{H}_{2} \mathrm{O}(4.6 \mathrm{mg}), 0.2 \mathrm{M}$ HEPES buffer $(47.6 \mathrm{~g})$, biotin $(3.05 \mathrm{mg}), 1 \mathrm{X}$ dilution Trace Metal Mix A5 (Sigma), and 1X M9Media (Sigma), per liter of deionized water, and was supplemented with $1 \%$ glycerol.

For curing of editing plasmids, the growth conditions of $P$. thermoglucosidasius NCIMB 11955 were changed. The temperature was raised from $52{ }^{\circ} \mathrm{C}$ to $60{ }^{\circ} \mathrm{C}$, and the selection pressure of kanamycin was removed. The cultures were grown in 2 SPYNG $(10 \mathrm{~mL})$ at $60{ }^{\circ} \mathrm{C}$ in a falcon tube for $12 \mathrm{~h}$ before being passaged into fresh media six successive times. The cultures were then serially diluted to $1 \times 10^{-4}$ and plated onto TSA plates and grown $\mathrm{O} / \mathrm{N}$ to produce single colonies. These single colonies were then screened to identify the plasmiddeficient strain by replica plating onto TSA plates with and without kanamycin. 
Reagents. All PCR reactions were performed using Phusion 2X Master Mix (New England Biolabs) or DreamTaq Green PCR Master Mix (Thermo Fisher Scientific). T4 ligase (Promega) was used for DNA ligation reactions. Restriction enzymes were purchased from Thermo Fisher Scientific. A Q5 Site-Directed Mutagenesis Kit (New England Biolabs) was used for site-directed mutagenesis.

Plasmid Design and Construction. Oligonucleotide primers were synthesized by Sigma-Aldrich and are listed in Table S5. Plasmids were constructed by restriction enzymebased cloning procedures. ${ }^{68}$ Constructs were verified by DNA sequencing (Source Bioscience UK Limited). All the plasmids used in this study are listed in Table S6 and may be sourced from www.plasmidvectors.com. The sequences of plasmids pMTL575555 and pMTL675555 are available from GenBank, Accession Numbers MZ182078 and MZ182077, respectively. The plasmid pMTL61110 ${ }^{17}$ was used as the base chassis for all of the plasmids constructed in this study. To test the different Shine-Dalgarno sequences, site-directed mutagenesis was used to alter the sequences accordingly. To test the different terminators, a forward and reverse oligonucleotide sequence corresponding to each terminator was annealed to produce double-stranded construct. This construct was then cloned into the modular vector using standard restriction based cloning procedures. Homology cassettes used in this study were produced using splicing by overlap extension polymerase chain reaction (SOE-PCR).

Oligonucleotide Design, Analysis, and Synthesis. Oligonucleotides for synthetic guide RNA (sgRNA), for polymerase chain reaction (PCR), and for sequencing of DNA sequences were designed manually. Secondary structure of oligonucleotides was analyzed for the production of primers and for calculating the free energy of Rho-independent terminators. DNA sequences were analyzed using the OligoAnalyzer tool (https://www.idtdna.com/calc/analyzer) of Integrated DNA Technologies. Oligonucleotide synthesis was performed by Sigma-Aldrich. Spacer acquisition for sgRNA was completed using Benchling CRISPR Guide Design software (www.benchling.com).

Transformation of Plasmid DNA. All E. coli strains were transformed using the heat-shock method. Plasmid DNA (1-2 $\mu \mathrm{L})(100-500 \mathrm{ng} / \mu \mathrm{L})$ was added to chemical competent $E$. coli Top10 cells $(60 \mu \mathrm{L})$. This mixture was left on ice for $30-$ $45 \mathrm{~min}$, then transferred to $42{ }^{\circ} \mathrm{C}$ for $30 \mathrm{~s}$, and then returned back to ice for 3-5 min. LB media $(900 \mu \mathrm{L})$ was then added to the cells and left to recover for $1.5 \mathrm{~h}$, incubated at $37{ }^{\circ} \mathrm{C}$, and shaken $(200 \mathrm{rpm})$. After recovery, the cells $(200 \mu \mathrm{L})$ were plated onto LB agar plates containing the appropriate antibiotic selection.

Transformation of $P$. thermoglucosidasius was conducted following the procedure described by Cripps et al. (2009). ${ }^{15}$ Plasmid DNA $(5 \mu \mathrm{L})(100-500 \mathrm{ng} / \mu \mathrm{L})$ was added to electrocompetent $P$. thermoglucosidasius NCIMB 11955 cells $(60 \mu \mathrm{L})$ in a precooled $1 \mathrm{~mm}$ gap electroporation cuvette. Electroporation was carried out using a GenePulser (BioRad), set at $600 \Omega, 2.5 \mathrm{kV}$, and $10 \mu \mathrm{FD}$. Immediately following the pulse, prewarmed 2 SPY $(1 \mathrm{~mL})$ was added to the cells and left to recover for $2.5-4 \mathrm{~h}$, incubated at $52^{\circ} \mathrm{C}$ shaking $(250 \mathrm{rpm})$. After recovery, the cells were concentrated by centrifugation $(5000 \mathrm{~g}, 5 \mathrm{~min})$ and resuspended in $2 \mathrm{SPY}$ media $(200 \mu \mathrm{L})$ before being plated onto prewarmed TSA agar plates containing kanamycin $(12.5 \mu \mathrm{g} / \mathrm{mL})$.
Production of $\mathbf{p} \Delta$ Cas9. For the vector $\mathrm{p} \Delta$ Cas9, we produced a frame shifted variant of each cas 9 . This was achieved through the use of the restriction endonuclease enzymes PacI and Eco81I, respectively, to cut the genes. The genes were then subjected to T4 DNA polymerase, which has the ability to form blunt ends by the removal of $3^{\prime}$ overhangs or by filling-in $5^{\prime}$ overhangs. These blunt ends were then ligated together to produce the complete but inactivated cas 9 gene.

Analytical Methods. The eCGP123 assay used to determine the relative levels of gene expression was carried out as follows. The constructed gene expression vectors were transformed into $P$. thermoglucosidasius competent cells. After recovery, the transformed cells were plated onto TSA plates containing kanamycin $(12.5 \mu \mathrm{g} / \mathrm{mL})$ and grown $\mathrm{O} / \mathrm{N}$. A single colony was picked and restreaked onto TSA plates containing kanamycin. A single colony was picked and cultured in a baffled conical flask for $8 \mathrm{~h}$ at $250 \mathrm{rpm}$, in 2SPYNG media containing kanamycin $(12.5 \mu \mathrm{g} / \mathrm{mL})$, before extracting the protein lysate. The level of eCGP123 was measured using a microplate reader (CLARIOstar) using the excitation and emission values determined by Don Paul et al. (2011). ${ }^{37}$ The relative fluorescence intensities (RFUs) were then normalized using the protein concentration of each sample. Protein concentration was calculated using a Pierce BCA Protein Assay Kit (Thermo Fisher Scientific). Protein extraction was carried out using BugBuster 10X protein extraction reagent (Merck). The protein extraction buffer (1X) consisted of BugBuster 10X $(2 \mathrm{~mL})$, sodium phosphate buffer $50 \mathrm{mM}(18 \mathrm{~mL})$, EDTA-free protease inhibitor tablet (Roche), and lysozyme $(20 \mathrm{mg} / \mathrm{mL})$.

Metabolites produced by $P$. thermoglucosidasius were analyzed using high-performance liquid chromatography (HPLC-UV), performed using the Dionex UltiMate 3000 System. $5 \mathrm{mM} \mathrm{H}_{2} \mathrm{SO}_{4}$ was used as the mobile phase. The sample supernatant was mixed, in a 1:1 ratio, with diluent, which consisted of the mobile phase mixed with $50 \mathrm{mM}$ valeric acid. Samples were filtered to remove particulate matter through $0.2 \mu \mathrm{m}$ syringe filters directly into HPLC vials containing $300 \mu \mathrm{L}$ inserts with split caps. The samples were run on the Bio-Rad Aminex HPX-87H $300 \mathrm{~mm} \times 7.8 \mathrm{~mm} \times 9$ $\mu \mathrm{m}$ column, at a flow rate of $0.5 \mathrm{~mL} / \mathrm{min}$, at $35^{\circ} \mathrm{C}$ for $55 \mathrm{~min}$.

\section{ASSOCIATED CONTENT}

\section{Supporting Information}

The Supporting Information is available free of charge at https://pubs.acs.org/doi/10.1021/acssynbio.1c00138.

Promoter sequences (Table S1); Shine-Dalgarno sequences (Table S2); terminator sequences (Table S3); strains used in this study (Table S4); primers used in this study (Table S5); plasmids used in this study (Table S6); and metabolite and glycerol utilization profile of the plasmid-deficient strains (Figure S1) (PDF)

\section{AUTHOR INFORMATION}

\section{Corresponding Author}

Nigel P. Minton - BBSRC/EPSRC Synthetic Biology Research Centre (SBRC), Biodiscovery Institute, School of Life Sciences, University of Nottingham, Nottingham NG7 2RD, U.K.; 이이.org/0000-0002-9277-1261; Email: nigel.minton@nottingham.ac.uk 


\section{Authors}

Matthew S. H. Lau - BBSRC/EPSRC Synthetic Biology Research Centre (SBRC), Biodiscovery Institute, School of Life Sciences, University of Nottingham, Nottingham NG7 2RD, U.K.

Lili Sheng - BBSRC/EPSRC Synthetic Biology Research Centre (SBRC), Biodiscovery Institute, School of Life Sciences, University of Nottingham, Nottingham NG7 2RD, U.K.

Ying Zhang - BBSRC/EPSRC Synthetic Biology Research Centre (SBRC), Biodiscovery Institute, School of Life Sciences, University of Nottingham, Nottingham NG7 2RD, U.K.

Complete contact information is available at:

https://pubs.acs.org/10.1021/acssynbio.1c00138

\section{Author Contributions}

N.P.M. conceived the study; M.S.H.L., Y.Z., L.S., and N.P.M. designed the experiments; M.S.H.L. performed the experiments; and M.S.H.L. and N.P.M. wrote the manuscript. All authors approved the final version.

\section{Notes}

The authors declare no competing financial interest.

\section{ACKNOWLEDGMENTS}

This work was supported by the UK Biotechnology and Biological Sciences Research Council [grant numbers BB/ L016478/1 and BB/N022718/1] through the award of a CASE studentship to M.S.H.L. supported by ATUM (formerly DNA2.0) and the support of L.S. through the IB Catalyst grant MAXIBIO. We thank Peter Rowe for discussions on the CRISPR/Cas9 system present in Streptococcus thermophilus, Matthew Abbott for assistance with HPLC-UV analysis, and all members of SBRC who helped to carry out this research.

\section{ABBREVIATIONS}

KIs, knock-ins; KOs, knockouts; CRISPR, clustered regularly interspaced short palindromic repeats; Cas, CRISPR-associated protein; PAM, protospacer-adjacent motif; sgRNA, synthetic guide RNA; spCas9, Streptococcus pyogenes cas9; stCas9, Streptococcus thermophilus cas9; sfGFP, superfolder green fluorescent protein; SD, Shine-Dalgarno; HA, homology arms; HR, homologous recombination; HPLC-UV, highperformance liquid chromatography-ultraviolet; SOE-PCR, splicing by overlap extension polymerase chain reaction

\section{REFERENCES}

(1) Lynd, L. R., Weimer, P. J., van Zyl, W. H., and Pretorius, I. S. (2002) Microbial cellulose utilization: fundamentals and biotechnology. Microbiol. Mol. Biol. Rev. 66, 506-577.

(2) Demain, A. L., Newcomb, M., and Wu, J. H. (2005) Cellulase, clostridia, and ethanol. Microbiol. Mol. Biol. Rev. 69, 124-154.

(3) Taylor, M. P., Eley, K. L., Martin, S., Tuffin, M. I., Burton, S. G., and Cowan, D. A. (2009) Thermophilic ethanologenesis: future prospects for second-generation bioethanol production. Trends Biotechnol. 27, 398-405.

(4) Olson, D. G., Sparling, R., and Lynd, L. R. (2015) Ethanol production by engineered thermophiles. Curr. Opin. Biotechnol. 33, 130-141.

(5) Bischoff, K. M., Skinner-Nemec, K. A., and Leathers, T. D. (2007) Antimicrobial susceptibility of Lactobacillus species isolated from commercial ethanol plants. J. Ind. Microbiol. Biotechnol. 34, 739744.
(6) Skinner, K. A., and Leathers, T. D. (2004) Bacterial contaminants of fuel ethanol production. J. Ind. Microbiol. Biotechnol. 31, 401-408.

(7) Bhalla, A., Bansal, N., Kumar, S., Bischoff, K. M., and Sani, R. K. (2013) Improved lignocellulose conversion to biofuels with thermophilic bacteria and thermostable enzymes. Bioresour. Technol. 128, 751-759.

(8) Lin, P. P., Rabe, K. S., Takasumi, J. L., Kadisch, M., Arnold, F. H., and Liao, J. C. (2014) Isobutanol production at elevated temperatures in thermophilic Geobacillus thermoglucosidasius. Metab. Eng. 24, 1-8.

(9) Olson, D. G., McBride, J. E., Shaw, A. J., and Lynd, L. R. (2012) Recent progress in consolidated bioprocessing. Curr. Opin. Biotechnol. 23, 396-405.

(10) Haki, G. D., and Rakshit, S. K. (2003) Developments in industrially important thermostable enzymes: a review. Bioresour. Technol. 89, 17-34.

(11) Turner, P., Mamo, G., and Karlsson, E. N. (2007) Potential and utilization of thermophiles and thermostable enzymes in biorefining. Microb. Cell Fact. 6, 9.

(12) Taylor, M. P., van Zyl, L., Tuffin, I. M., Leak, D. J., and Cowan, D. A. (2011) Genetic tool development underpins recent advances in thermophilic whole-cell biocatalysts. Microb. Biotechnol. 4, 438-448.

(13) Aliyu, H., Lebre, P., Blom, J., Cowan, D., and De Maayer, P. (2016) Phylogenomic re-assessment of the thermophilic genus Geobacillus. Syst. Appl. Microbiol. 39, 527-533.

(14) Nazina, T. N., Tourova, T. P., Poltaraus, A. B., Novikova, E. V., Grigoryan, A. A., Ivanova, A. E., Lysenko, A. M., Petrunyaka, V. V., Osipov, G. A., Belyaev, S. S., and Ivanov, M. V. (2001) Taxonomic study of aerobic thermophilic bacilli: descriptions of Geobacillus subterraneus gen. nov., sp nov and Geobacillus uzenensis sp nov from petroleum reservoirs and transfer of Bacillus stearothermophilus, Bacillus thermocatenulatus, Bacillus thermoleovorans, Bacillus kaustophilus, Bacillus thermoglucosidasius and Bacillus thermodenitrificans to Geobacillus as the new combinations G. stearothermophilus, G. thermocatenulatus, G. thermoleovorans, G. kaustophilus, G. thermoglucosidasius and G. thermodenitrificans. Int. J. Syst. Evol. Microbiol. 51, 433-446.

(15) Cripps, R. E., Eley, K., Leak, D. J., Rudd, B., Taylor, M., Todd, M., Boakes, S., Martin, S., and Atkinson, T. (2009) Metabolic engineering of Geobacillus thermoglucosidasius for high yield ethanol production. Metab. Eng. 11, 398-408.

(16) Raita, M., Ibenegbu, C., Champreda, V., and Leak, D. J. (2016) Production of ethanol by thermophilic oligosaccharide utilising Geobacillus thermoglucosidasius TM242 using palm kernel cake as a renewable feedstock. Biomass Bioenergy 95, 45-54.

(17) Sheng, L., Kovacs, K., Winzer, K., Zhang, Y., and Minton, N. P. (2017) Development and implementation of rapid metabolic engineering tools for chemical and fuel production in Geobacillus thermoglucosidasius NCIMB 11955. Biotechnol. Biofuels 10, 5.

(18) Zhou, J., Wu, K., and Rao, C. V. (2016) Evolutionary engineering of Geobacillus thermoglucosidasius for improved ethanol production. Biotechnol. Bioeng. 113, 2156-2167.

(19) Boeke, J. D., LaCroute, F., and Fink, G. R. (1984) A positive selection for mutants lacking orotidine-5'-phosphate decarboxylase activity in yeast: 5-fluoro-orotic acid resistance. Mol. Gen. Genet. 197, 345-346.

(20) Barrangou, R., Fremaux, C., Deveau, H., Richards, M., Boyaval, P., Moineau, S., Romero, D. A., and Horvath, P. (2007) CRISPR provides acquired resistance against viruses in prokaryotes. Science $315,1709-1712$.

(21) Jansen, R., Embden, J. D., Gaastra, W., and Schouls, L. M. (2002) Identification of genes that are associated with DNA repeats in prokaryotes. Mol. Microbiol. 43, 1565-1575.

(22) Mojica, F. J., Diez-Villasenor, C., Garcia-Martinez, J., and Soria, E. (2005) Intervening sequences of regularly spaced prokaryotic repeats derive from foreign genetic elements. J. Mol. Evol. 60, 174182. 
(23) Makarova, K. S., Grishin, N. V., Shabalina, S. A., Wolf, Y. I., and Koonin, E. V. (2006) A putative RNA-interference-based immune system in prokaryotes: computational analysis of the predicted enzymatic machinery, functional analogies with eukaryotic RNAi, and hypothetical mechanisms of action. Biol. Direct 1, 7.

(24) Jinek, M., Chylinski, K., Fonfara, I., Hauer, M., Doudna, J. A., and Charpentier, E. (2012) A programmable dual-RNA-guided DNA endonuclease in adaptive bacterial immunity. Science 337, 816-821.

(25) Jiang, W., Bikard, D., Cox, D., Zhang, F., and Marraffini, L. A. (2013) RNA-guided editing of bacterial genomes using CRISPR-Cas systems. Nat. Biotechnol. 31, 233-239.

(26) Mali, P., Yang, L., Esvelt, K. M., Aach, J., Guell, M., DiCarlo, J. E., Norville, J. E., and Church, G. M. (2013) RNA-guided human genome engineering via Cas9. Science 339, 823-826.

(27) Oh, J. H., and van Pijkeren, J. P. (2014) CRISPR-Cas9-assisted recombineering in Lactobacillus reuteri. Nucleic Acids Res. 42, e131.

(28) Barrangou, R., and van Pijkeren, J. P. (2016) Exploiting CRISPR-Cas immune systems for genome editing in bacteria. Curr. Opin. Biotechnol. 37, 61-68.

(29) Li, Y., Lin, Z., Huang, C., Zhang, Y., Wang, Z., Tang, Y. J., Chen, T., and Zhao, X. (2015) Metabolic engineering of Escherichia coli using CRISPR-Cas9 meditated genome editing. Metab. Eng. 31, $13-21$.

(30) Huang, H., Chai, C., Li, N., Rowe, P., Minton, N. P., Yang, S., Jiang, W., and Gu, Y. (2016) CRISPR/Cas9-Based Efficient Genome Editing in Clostridium ljungdahlii, an Autotrophic Gas-Fermenting Bacterium. ACS Synth. Biol. 5, 1355-1361.

(31) Mougiakos, I., Bosma, E. F., Weenink, K., Vossen, E., Goijvaerts, K., van der Oost, J., and van Kranenburg, R. (2017) Efficient Genome Editing of a Facultative Thermophile Using Mesophilic spCas9. ACS Synth. Biol. 6, 849-861.

(32) Mougiakos, I., Mohanraju, P., Bosma, E. F., Vrouwe, V., Finger Bou, M., Naduthodi, M. I. S., Gussak, A., Brinkman, R. B. L., van Kranenburg, R., and van der Oost, J. (2017) Characterizing a thermostable Cas 9 for bacterial genome editing and silencing. Nat. Commun. 8, 1647.

(33) Bolotin, A., Quinquis, B., Renault, P., Sorokin, A., Ehrlich, S. D., Kulakauskas, S., Lapidus, A., Goltsman, E., Mazur, M., Pusch, G. D., Fonstein, M., Overbeek, R., Kyprides, N., Purnelle, B., Prozzi, D., Ngui, K., Masuy, D., Hancy, F., Burteau, S., Boutry, M., Delcour, J., Goffeau, A., and Hols, P. (2004) Complete sequence and comparative genome analysis of the dairy bacterium Streptococcus thermophilus. Nat. Biotechnol. 22, 1554-1558.

(34) Bolotin, A., Quinquis, B., Sorokin, A., and Ehrlich, S. D. (2005) Clustered regularly interspaced short palindrome repeats (CRISPRs) have spacers of extrachromosomal origin. Microbiology 151, 25512561

(35) Horvath, P., Romero, D. A., Coute-Monvoisin, A. C., Richards, M., Deveau, H., Moineau, S., Boyaval, P., Fremaux, C., and Barrangou, R. (2008) Diversity, activity, and evolution of CRISPR loci in Streptococcus thermophilus. J. Bacteriol. 190, 1401-1412.

(36) Kiss, C., Temirov, J., Chasteen, L., Waldo, G. S., and Bradbury, A. R. (2009) Directed evolution of an extremely stable fluorescent protein. Protein Eng., Des. Sel. 22, 313-323.

(37) Don Paul, C., Traore, D. A., Byres, E., Rossjohn, J., Devenish, R. J., Kiss, C., Bradbury, A., Wilce, M. C., and Prescott, M. (2011) Expression, purification, crystallization and preliminary $\mathrm{X}$-ray analysis of eCGP123, an extremely stable monomeric green fluorescent protein with reversible photoswitching properties. Acta Crystallogr., Sect. F: Struct. Biol. Cryst. Commun. 67, 1266-1268.

(38) Henche, A. L., Koerdt, A., Ghosh, A., and Albers, S. V. (2012) Influence of cell surface structures on crenarchaeal biofilm formation using a thermostable green fluorescent protein. Environ. Microbiol. 14, 779-793.

(39) Cava, F., de Pedro, M. A., Blas-Galindo, E., Waldo, G. S., Westblade, L. F., and Berenguer, J. (2008) Expression and use of superfolder green fluorescent protein at high temperatures in vivo: a tool to study extreme thermophile biology. Environ. Microbiol. 10, 605-613.
(40) Blanchard, K., Robic, S., and Matsumura, I. (2014) Transformable facultative thermophile Geobacillus stearothermophilus NUB3621 as a host strain for metabolic engineering. Appl. Microbiol. Biotechnol. 98, 6715-6723.

(41) Reeve, B., Martinez-Klimova, E., de Jonghe, J., Leak, D. J., and Ellis, T. (2016) The Geobacillus Plasmid Set: A Modular Toolkit for Thermophile Engineering. ACS Synth. Biol. 5, 1342-1347.

(42) Orosz, A., Boros, I., and Venetianer, P. (1991) Analysis of the complex transcription termination region of the Escherichia coli $\mathrm{rrnB}$ gene. Eur. J. Biochem. 201, 653-659.

(43) Esvelt, K. M., Mali, P., Braff, J. L., Moosburner, M., Yaung, S. J., and Church, G. M. (2013) Orthogonal Cas9 proteins for RNA-guided gene regulation and editing. Nat. Methods 10, 1116-1121.

(44) Kleinstiver, B. P., Prew, M. S., Tsai, S. Q., Topkar, V. V., Nguyen, N. T., Zheng, Z., Gonzales, A. P., Li, Z., Peterson, R. T., Yeh, J. R., Aryee, M. J., and Joung, J. K. (2015) Engineered CRISPR-Cas9 nucleases with altered PAM specificities. Nature 523, 481-485.

(45) Xu, K., Ren, C., Liu, Z., Zhang, T., Zhang, T., Li, D., Wang, L., Yan, Q., Guo, L., Shen, J., and Zhang, Z. (2015) Efficient genome engineering in eukaryotes using Cas9 from Streptococcus thermophilus. Cell. Mol. Life Sci. 72, 383-399.

(46) Muller, M., Lee, C. M., Gasiunas, G., Davis, T. H., Cradick, T. J., Siksnys, V., Bao, G., Cathomen, T., and Mussolino, C. (2016) Streptococcus thermophilus CRISPR-Cas9 Systems Enable Specific Editing of the Human Genome. Mol. Ther. 24, 636-644.

(47) Garneau, J. E., Dupuis, M. E., Villion, M., Romero, D. A., Barrangou, R., Boyaval, P., Fremaux, C., Horvath, P., Magadan, A. H., and Moineau, S. (2010) The CRISPR/Cas bacterial immune system cleaves bacteriophage and plasmid DNA. Nature 468, 67-71.

(48) Magadan, A. H., Dupuis, M. E., Villion, M., and Moineau, S. (2012) Cleavage of phage DNA by the Streptococcus thermophilus CRISPR3-Cas system. PLoS One 7, e40913.

(49) Sapranauskas, R., Gasiunas, G., Fremaux, C., Barrangou, R., Horvath, P., and Siksnys, V. (2011) The Streptococcus thermophilus CRISPR/Cas system provides immunity in Escherichia coli. Nucleic Acids Res. 39, 9275-9282.

(50) Shaw, A. J., Podkaminer, K. K., Desai, S. G., Bardsley, J. S., Rogers, S. R., Thorne, P. G., Hogsett, D. A., and Lynd, L. R. (2008) Metabolic engineering of a thermophilic bacterium to produce ethanol at high yield. Proc. Natl. Acad. Sci. U. S. A. 105, 13769-13774.

(51) Phue, J. N., Lee, S. J., Kaufman, J. B., Negrete, A., and Shiloach, J. (2010) Acetate accumulation through alternative metabolic pathways in ackA (-) pta (-) poxB (-) triple mutant in E. coli B (BL21). Biotechnol. Lett. 32, 1897-1903.

(52) Kuit, W., Minton, N. P., Lopez-Contreras, A. M., and Eggink, G. (2012) Disruption of the acetate kinase (ack) gene of Clostridium acetobutylicum results in delayed acetate production. Appl. Microbiol. Biotechnol. 94, 729-741.

(53) Stouthamer, A. H., and Kooijman, S. A. (1993) Why it pays for bacteria to delete disused DNA and to maintain megaplasmids. Antonie van Leeuwenhoek 63, 39-43.

(54) Smillie, C., Garcillan-Barcia, M. P., Francia, M. V., Rocha, E. P., and de la Cruz, F. (2010) Mobility of plasmids. Microbiol. Mol. Biol. Rev. 74, 434-452.

(55) Sheng, L., Zhang, Y., and Minton, N. P. Complete Genome Sequence of Geobacillus thermoglucosidasius NCIMB 11955, the Progenitor of a Bioethanol Production Strain. Genome Announc, 2016; Vol. 4.

(56) Oresnik, I. J., Liu, S. L., Yost, C. K., and Hynes, M. F. (2000) Megaplasmid pRme2011a of Sinorhizobium meliloti is not required for viability. J. Bacteriol. 182, 3582-3586.

(57) Romanchuk, A., Jones, C. D., Karkare, K., Moore, A., Smith, B. A., Jones, C., Dougherty, K., and Baltrus, D. A. (2014) Bigger is not always better: transmission and fitness burden of approximately $1 \mathrm{MB}$ Pseudomonas syringae megaplasmid pMPPla107. Plasmid 73, 16-25.

(58) Ohtani, N., Tomita, M., and Itaya, M. (2016) Curing the Megaplasmid pTT27 from Thermus thermophilus HB27 and Maintaining Exogenous Plasmids in the Plasmid-Free Strain. Appl. Environ. Microbiol. 82, 1537-1548. 
(59) Hynes, M. F., Quandt, J., O’Connell, M. P., and Pühler, A. (1989) Direct selection for curing and deletion of Rhizobium plasmids using transposons carrying the Bacillus subtilis sacB gene. Gene 78, 111-120.

(60) Gerdes, K., Rasmussen, P. B., and Molin, S. (1986) Unique type of plasmid maintenance function: postsegregational killing of plasmid-free cells. Proc. Natl. Acad. Sci. U. S. A. 83, 3116-3120.

(61) Thisted, T., Sorensen, N. S., Wagner, E. G., and Gerdes, K. (1994) Mechanism of post-segregational killing: Sok antisense RNA interacts with Hok mRNA via its $5^{\prime}$-end single-stranded leader and competes with the $3^{\prime}$-end of Hok mRNA for binding to the mok translational initiation region. EMBO J. 13, 1960-1968.

(62) Szekeres, S., Dauti, M., Wilde, C., Mazel, D., and RoweMagnus, D. A. (2007) Chromosomal toxin-antitoxin loci can diminish large-scale genome reductions in the absence of selection. Mol. Microbiol. 63, 1588-1605.

(63) Tsilibaris, V., Maenhaut-Michel, G., Mine, N., and Van Melderen, L. (2007) What is the benefit to Escherichia coli of having multiple toxin-antitoxin systems in its genome? J. Bacteriol. 189, 6101-6108.

(64) Van Melderen, L. (2010) Toxin-antitoxin systems: why so many, what for? Curr. Opin. Microbiol. 13, 781-785.

(65) Liu, M., Zhang, Y., Inouye, M., and Woychik, N. A. (2008) Bacterial addiction module toxin Doc inhibits translation elongation through its association with the $30 \mathrm{~S}$ ribosomal subunit. Proc. Natl. Acad. Sci. U. S. A. 105, 5885-5890.

(66) Van Melderen, L., and Saavedra De Bast, M. (2009) Bacterial toxin-antitoxin systems: more than selfish entities? PLoS Genet. 5, e1000437.

(67) Botelho, J., Lood, C., Partridge, S. R., van Noort, V., Lavigne, R., Grosso, F., and Peixe, L. (2019) Combining sequencing approaches to fully resolve a carbapenemase-encoding megaplasmid in a Pseudomonas shirazica clinical strain. Emerging Microbes Infect. 8, $1186-1194$

(68) Sambrook, J. F., and Russell, D. Molecular Cloning: A Laboratory Manual; 2001; Vol. 1. 